\title{
PROFIL BERPIKIR GEOMETRIS SISWA SMP DALAM MENYELESAIKAN SOAL GEOMETRI DITINJAU DARI LEVEL BERPIKIR VAN HIELE
}

\author{
Salma Mu'allimatur Rahmah \\ Pendidikan Matematika, FMIPA, Universitas Negeri Surabaya, e-mail: salmarahmah@mhs.unesa.ac.id
}

\author{
Susanah \\ Pendidikan Matematika, FMIPA, Universitas Negeri Surabaya, e-mail: susanah@unesa.ac.id
}

\begin{abstract}
Abstrak
Berpikir geometris merupakan serangkaian aktivitas yang dilakukan oleh siswa dalam menyelesaikan soal geometri meliputi visualisasi, konstruksi, dan penalaran. Terdapat perbedaan dalam proses berpikir geometris yang dilakukan para siswa dalam menyelesaikan soal. Salah satu yang mempengaruhi proses berpikir geometris siswa adalah level berpikir Van Hiele. Penelitian ini merupakan penelitian deskriptif kualitatif yang bertujuan untuk mendeskripsikan profil berpikir geometris siswa dalam menyelesaikan soal geometri ditinjau dari level berpikir Van Hiele. Subjek penelitian ini terdiri dari tiga siswa kelas IX SMP dengan tingkat berpikir Van Hiele yang berbeda yang dipilih berdasarkan hasil tes level berpikir Van Hiele yang dilakukan. Hasil menunjukkan subjek level 0 melakukan kesalahan dalam ketiga aktivitas kognitif berpikir geometris. Subjek level 0 mengkonstruksi objek geometri tidak berdasarkan aturan geometris, melakukan kesalahan dalam memvisualisasikan objek geometri, dan melakukan kesalahan dalam menarik kesimpulan. Subjek level 1 melakukan proses visualisasi dan konstruksi dengan benar, tetapi melakukan kesalahan dalam proses penalaran karena ketidaktelitian dalam perhitungan matematis. Subjek level 2 melakukan proses visualisasi, konstruksi, dan penalaran dengan benar.
\end{abstract}

Kata Kunci: berpikir geometri, level berpikir Van Hiele, soal geometri.

\begin{abstract}
Geometric thinking is a series of activities carried out by students in solving geometric problems including visualization, construction, and reasoning. There are differences in the geometric thinking processes that students do in solving problems. One thing that influences students' geometric thinking process is Van Hiele's level of thinking. This research is a qualitative descriptive study which aims to describe the geometric thinking profile of students in solving geometry problems in terms of Van Hiele's thinking level. The subjects of this study consisted of three students of class IX JHS with different Van Hiele thinking levels who were selected based on the results of the Van Hiele thinking level test conducted. The results showed that level 0 subjects made mistakes in all three cognitive activities of geometric thinking. Level 0 subjects construct geometric objects not based on geometric rules, make mistakes in visualizing geometric objects, and make mistakes in drawing conclusions. Level 1 subjects performed the visualization and construction processes correctly, but made mistakes in the reasoning process due to inaccuracies in mathematical calculations. Level 2 subjects carry out the visualization, construction, and reasoning processes correctly.
\end{abstract}

Keywords: geometric thinking, Van Hiele level's, geometry problem

\section{PENDAHULUAN}

Geometri merupakan salah satu cabang matematika yang banyak diterapkan dalam kehidupan sehari-hari. Abdullah (2013: 252) mengatakan "Geometry is a basic skill to be mastered. It is important in architecture and design, in engineering, and in various aspects of contruction work." Geometri adalah keterampilan dasar yang harus dikuasai. Penerapan geometri memiliki peran penting dalam kehidupan seperti pada arsitektur dan desain, teknik, dan berbagai aspek pekerjaan yang berhubungan dengan konstruksi. Geometri juga berperan sebagai tonggak dasar perkembangan ilmu matematika seperti Phytagoras, Kalkulus, Aljabar, dan disiplin ilmu lainnya seperti Astronomi melalui representasi dari luas bidang (Burton, 2011). Geometri dapat membantu siswa memahami matematika melalui representasi geometris seperti pecahan dan perkalian dalam aritmatika, hubungan antara grafik fungsi (dua dan tiga variabel), dan representasi grafis data dalam statistika. Dalam pendidikan, geometri berkontribusi untuk membantu siswa dalam mengembangkan keterampilan visualisasi, penalaran, berpikir kritis, dan pemecahan masalah (Aydogdu, 2014). Seperti yang diungkapkan Walle (2001:307) "Like all mathematics, 
geometry is best developed in a spirit of problem solving". Hal ini menjadikan geometri sebagai subjek pembelajaran yang sangat penting untuk diperhatikan.

Pentingnya peranan geometri dalam pendidikan menjadikannya salah satu dari empat lingkup materi yang diujikan dalam Ujian Nasional pada pelajaran matematika. Kemendikbud menjabarkan hasil Ujian Nasional SMP tahun 2019 pada subjek geometri dalam soal matematika hanya $42,27 \%$ siswa menjawab dengan benar dan $57,73 \%$ siswa menjawab salah (Kemendikbud, 2019). Data tersebut membuktikan bahwa sebagian besar siswa SMP di Indonesia belum memahami konsep geometri secara utuh. Hal ini juga diperkuat dari hasil beberapa penelitian (Puspitasari, 2018; Mufidah, 2018; Ningrum, 2016) yang menunjukkan bahwa beberapa siswa SMP masih melakukan miskonsepsi dalam memahami konsep geometri. Berdasarkan data-data tersebut diperlukan kajian mendalam oleh pendidik untuk mengetahui kesulitan siswa dalam memahami konsep-konsep yang ada pada geometri agar dapat menghindari miskonsepsi dan kesalahan dalam menyelesaikan soal-soal yang diberikan. Salah satunya adalah dengan mengetahui proses berpikir geometri siswa.

Seperti yang diungkapkan Hardianti, et al (2017:895) "In learning of geometry we must pay attention on student level thinking and learning process". Dalam mempelajari geometri pendidik harus menaruh perhatian pada level berpikir siswa dan proses pembelajaran. Abdullah (2013: 252) juga mengatakan "There are basically two objectives of geometry learning, which are to develop logical thinking skill and to develop spatial intuitions that refer to how one views space and area in real world". Pada dasarnya terdapat dua objek dalam pembelajaran geometri, yaitu mengembangkan kemampuan berpikir logika dan mengembangkan intuisi spasial yang mengacu pada bagaimana seseorang memandang ruang dan dan luasan di dunia nyata. Berpikir geometris berkaitan dengan bagaimana seseorang berpikir tentang sifat-sifat bentuk geometris dan hubungan spasial. Ide pokok dalam berpikir geometris adalah gagasan indra spasial tentang bagaimana siswa memahami bentuk dan hubungan spasial di antara objek geometri (Fisher, 2015). Beberapa teori yang mendasari tentang berpikir geometris diantaranya adalah model kognitif Duval tentang penalaran geometrik dan level berpikir Van Hiele (Jones, 1998).

Duval (1998:38) mengatakan "Geometry involves three kinds of cognitive processes which fulfil specific epistemological function: visualisation, construction, and reasoning". Duval berpendapat bahwa geometri melibatkan tiga jenis proses kognitif yang memenuhi epistemologis spesifik: visualisasi, konstruksi, dan penalaran. Hubungan antara ketiga jenis proses kognitif tersebut ditunjukkan dalam gambar berikut:

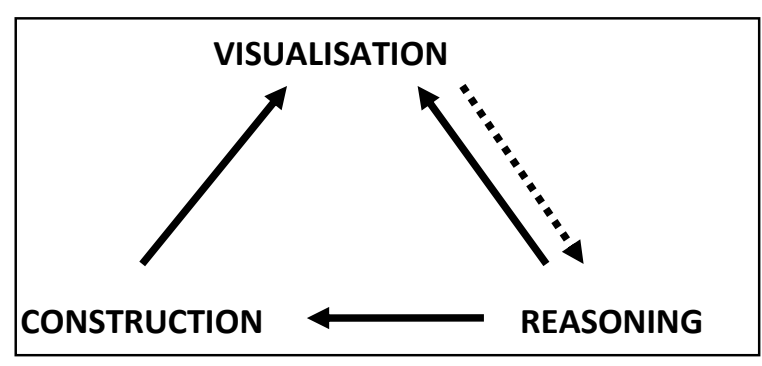

Gambar 1. interaksi kognitif dalam berpikir
geometri

Setiap anak panah merepresentasikan proses kognitif satu dapat mendukung proses kognitif yang lain. Duval (1998:38) mengatakan "however these three kinds of cognitive processes are closely connected and their synergy is cognitively necessary for proficiency in geometry". Ketiga jenis proses kognitif tersebut saling berkaitan erat dan sinerginya secara kognitif diperlukan untuk keterampilan dalam geometri.

Konyalioglu (2011:4042) mengatakan "by using visualization approach many mathematical concept can become concrete and clear for students to understand." Dengan pendekatan visualisasi banyak konsep matematika yang menjadi konkrit dan jelas bagi siswa untuk dapat memahami konsep tersebut. Keterampilan visualisasi sangat penting dimiliki oleh siswa agar dapat memahami bentuk-bentuk geometris. Duval (1995) mengatakan "Representation and Visualization are at the core of understanding in mathematics". Representasi dan visualisasi merupakan inti dalam memahami matematika. Proses visualisasi dalam berpikir geometris berkaitan dengan representasi seperti yang diungkapkan oleh Duval (1998:38) bahwa "visualization process with regard to space representation for the illustration of statement". Representasi merupakan konfigurasi yang dapat mewakili sesuatu dalam cara yang lain. Fajriah (2018) mengungkapkan terdapat dua proses dalam visualisasi yaitu: 1) visualisasi internal, membayangkan objek geometri berdasarkan informasi; 2) visualisasi eksternal, menggambar objek geometri berdasarkan informasi. Dari uraian tersebut dapat disimpulkan bahwa seorang siswa dikatakan melakukan visualisasi ketika telah melakukan transformasi bentuk dan memanipulasinya dengan pengetahuan terkait agar informasi yang disajikan dalam bentuk abstrak dapat lebih mudah dipahami.

Kontruksi geometri adalah suatu tata cara dalam menggambar suatu bentuk geometri dengan didasarkan pada konstruksi geometri dasar. Proses konstruksi dalam geometri berkaitan dengan proses menggambarkan objek matematika sesuai dengan sifat-sifat geometri yang ada (Duval, 1998). Proses konstruksi mengacu pada proses diskursif dan mengarah pada proses visual. Kontruksi geometris dapat memainkan peran untuk menghubungkan antara visualisasi dan penalaran deduktif seperti yang diungkapkan Yang (2016:110) "learning of geometric constructions has the potential to bridge the gap between visualization (visual process) and deductive reasoning (discursive process) in the sense of Duval”. Konstruksi 
geometris juga memiliki manfaat diantaranya memberikan kejelasan visual ke beberapa hubungan geometris, membuat sesuatu terlihat lebih nyata bagi siswa sekolah menengah, dan meningkatkan semangat eksplorasi dan penemuan (Yang, 2016). Dari uraian tersebut dapat disimpulkan bahwa konstruksi adalah penggambaran bentuk geometris dimana kontruksi konfigurasi tersebut didapat dari hasil pengamatan terkait objek matematika yang direpresentasikan.

Penalaran dalam proses berpikir geometris berhubungan dengan proses diskursif untuk perluasan pengetahuan, untuk bukti, dan untuk penjelasan (Duval, 1998). Proses diskursif mendukung proses konstruksi seperti yang dikatakan Yang (2016:110) bahwa "Construction draws on discursive process and leads to visual process. In order to justify what is constructed, not only natural discursive process, which embeds visual process, but also deductive discursive process are required". Konstruksi mengacu pada proses diskursif dan menuntun ke proses visual. Untuk menjustifikasi apa yang dikonstruksikan, tidak hanya proses diskursif yang natural, yang menyertakan proses visual, tetapi juga diperlukan proses diskursif deduktif. Dari penjelesan tersebut dapat disimpulkan bahwa proses penalaran dalam berpikir geometris berhubungan dengan proses diskursif yang mana digunakan untuk menjelaskan atau membuktikan sifat geometris melalui ucapan alami atau penalaran teoritis. Fajriah (2018) mengungkapkan terdapat lima aktivitas penalaran dalam berpikir geometris, di antaranya yaitu: 1) Mengidentifikasi informasi yang diketahui dari soal, 2) Mendeskripsikan materi yang digunakan untuk menyelesaikan soal, 3) Menganalisis alasan materi yang digunakan, 4) Mengklarifikasi solusi yang diperoleh, 5) Menarik kesimpulan.

Dari uraian mengenai aktivitas visualisasi, konstruksi, dan penalaran dalam berpikir geometris, berikut adalah indikator yang digunakan dalam penelitian ini yang sebelumnya mengadaptasi dari penelitian Fajriah (2018):

Tabel 1. Indikator berpikir geometri

\begin{tabular}{|c|c|c|}
\hline $\begin{array}{c}\text { Aktivitas } \\
\text { Berpikir } \\
\text { Geometris }\end{array}$ & Indikator yang muncul & Kode \\
\hline \multirow[t]{2}{*}{ Visualisasi } & \begin{tabular}{lr}
\multicolumn{2}{l}{ Memanipulasi atau } \\
mengubah bentuk & ide \\
geometri yang akan \\
digunakan & untuk \\
menyelesaikan soal &
\end{tabular} & V1 \\
\hline & $\begin{array}{l}\text { Menggambarkan bentuk } \\
\text { representasi pada media } \\
\text { kertas berdasarkan informasi } \\
\text { yang diketahui }\end{array}$ & $\mathrm{V} 2$ \\
\hline Konstruksi & $\begin{array}{l}\text { Menggambar objek geometri } \\
\text { sesuai aturan geometris } \\
\text { dalam menyelesaikan soal }\end{array}$ & K \\
\hline \multirow[t]{2}{*}{ Penalaran } & $\begin{array}{lr}\text { Mengungkapkan informasi } \\
\text { yang diketahui disertai } \\
\text { alasan logis }\end{array}$ & $\mathrm{P} 1$ \\
\hline & $\begin{array}{l}\text { Merencanakan cara } \\
\text { penyelesaian soal yang akan }\end{array}$ & $\mathrm{P} 2$ \\
\hline
\end{tabular}

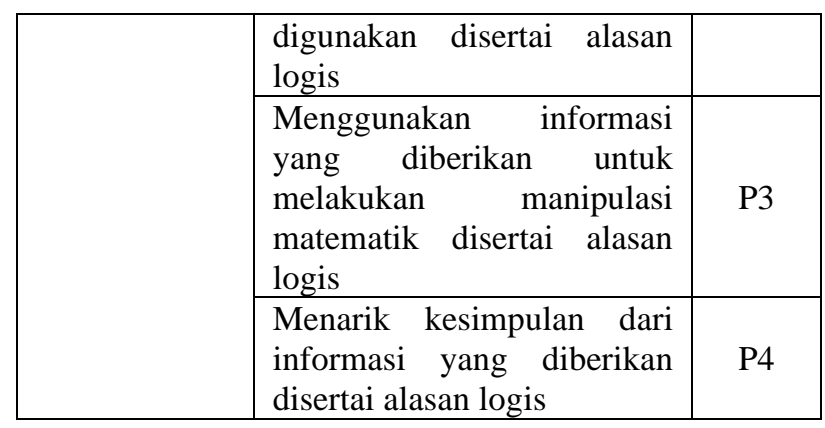

Salah satu yang mempengaruhi ketiga aktivitas kognitif dalam berpikir geometris siswa adalah level berpikir geometris. Sofyana (2013) dan Pratama (2017) mengungkapkan bahwa semakin tinggi level berpikir geometri siswa maka keterampilan geometri yang meliputi aktivitas visualisasi, menggambar bentuk, menalar, juga semakin baik. Berdasarkan teori Van Hiele, terdapat 5 level berpikir geomteri siswa. Level 0 visualisasi, level 1 analisis, level 2 deduksi informal, level 3 deduksi, dan level 4 rigor (Walle, 2010).

Beberapa penelitian yang telah dilakukan pada siswa di Indonesia mengungkapkan bahwa siswa SMP paling tinggi berada di level 2 dan sebagian besar masih berada di level 0 (Sofyana, 2013; Pratama, 2017). Beberapa siswa SMP juga melakukan miskonsepsi dalam memahami konsep bangun datar dan bangun tiga dimensi. Hal tersebut menunjukkan bahwa sebagian besar siswa belum memahami konsep geometri secara utuh. Adapun Kemendikbud yang menjabarkan hasil ujian nasional SMP tahun 2019 pada mata pelajaran matematika di lingkup materi geometri hanya $42,27 \%$ siswa menjawab soal geometri dengan benar dan 57,73\% lainnya menjawab salah. Dari data tersebut diperlukan adanya kajian mendalam untuk mengetahui kesulitan siswa dalam memahami konsep-konsep yang ada pada geometri.

Dengan mengetahui proses berpikir siswa, pendidik dapat memahami kesulitan siswa dalam menyelesaikan masalah yang ada. Hal ini senada dengan pendapat Duval (2006) bahwa kita harus menentukan fungsi kognitif yang mendasari keragaman proses matematika untuk memahami kesulitan yang dimiliki siswa. Dari uraian di atas, peneliti tertarik untuk melakukan penelitian yang berjudul "Profil Berpikir Geometris Siswa SMP dalam Menyelesaikan Soal Geometri Ditinjau dari Level Berpikir Van Hiele",

\section{METODE}

Penelitian ini merupakan penelitian deskriptif dengan pendekatan kualitatif. Penelitian ini bertujuan untuk mendeskripsikan profil berpikir geometris siswa SMP dalam menyelesaikan soal geometri ditinjau dari level berpikir Van Hiele. Penelitian ini dilaksanakan di SMP Negeri 1 Gresik pada semester ganjil tahun ajaran 2019/2020.

Instrumen yang digunakan dalam penelitian ini terdiri dari instrumen utama yaitu peneliti sendiri dan instrumen pendukung yang terdiri dari tes level berpikir Van Hiele 
yang bertujuan untuk mendapatkan subjek yang berada di level berpikir geometri Van Hiele yang berbeda, tes penyelesaian soal geometri yang bertujuan untuk mengetahui proses kognitif dalam aktivitas siswa menyelesaikan soal geometri, dan pedoman wawancara yang bertujuan untuk memverifikasi bagaimana langkah siswa dalam menyelesaikan soal geometri. Tes level berpikir Van Hiele diadopsi dari instrumen penelitian Sunardi (2005) yang sebelumnya telah dikembangkan oleh The Cognitive Development and Achievement in Secondary School Geometry Project (CDASSG). Tes penyelesaian soal geometri terdiri dari satu soal uraian yang memiliki satu jawaban benar dengan banyak cara penyelesaian. Pedoman wawancara berisi pertanyaan terkait langkah siswa dalam menyelesaikan soal. Soal geometri memuat pertanyaan menentukan luas limas segi empat beraturan (T.ABCD) yang terbentuk dari kubus ( $A B C D . E F G H$ ) dimana $A B C D$ merupakan bidang alas limas dan titik $T$ merupakan perpotongan diagonal $E G$ dan $F H$. Ketiga instrumen tersebut sebelumnya telah dikonsultasikan ke dosen pembimbing dan telah divalidasi oleh validator.

Tes level berpikir Van Hiele diberikan kepada siswa untuk mengetahui level Van Hiele yang dicapai oleh seluruh siswa dalam kelas tersebut. Berikut hasil dari tes level berpikir geometri yang dilakukan kepada 32 orang siswa kelas 9:

Tabel 2. Hasil tes level berpikir geometri

\begin{tabular}{|c|c|}
\hline Level yang dicapai & Jumlah anak \\
\hline Level 0 & 21 orang \\
\hline Level 1 & 9 orang \\
\hline Level 2 & 2 orang \\
\hline Level 3 & Tidak ada \\
\hline Level 4 & Tidak ada \\
\hline
\end{tabular}

Dari masing-masing kelompok level Van Hiele yang diperoleh, dipilih satu siswa sebagai subjek penelitian. Masing-masing subjek mewakili level 0, level 1, dan level 2. Pemilihan subjek berdasarkan atas saran dari guru mitra dan kekooperatifan siswa dalam penelitian ini. Setelah tes penyelesaian soal geometri dilaksanakan, peneliti melakukan wawancara kepada masing-masing subjek untuk memverifikasi dan mengetahui proses berpikir geometris siswa yang belum terungkap pada lembar jawaban.

Analisis data yang digunakan dalam penelitian ini adalah analisis data hasil tes penyelesaian soal geometri dan analisis data hasil wawancara. Analisis data hasil tes penyelesaian soal geometri digunakan untuk mengetahui proses kognitif apa saja yang dilakukan dengan benar oleh masing-masing subjek penelitian. Analisis dilakukan dengan mengacu pada indikator penelitian yang berada pada tabel 1.1.

\section{HASIL DAN PEMBAHASAN}
A. HASIL

Berikut adalah hasil analisis data tes penyelesaian soal geometri dan analisis data wawancara dari masing-masing subjek:

\section{Hasil Analisis Subjek Level 0 dalam Menyelesaikan} Soal Geometri

Dalam proses konstruksi dan visualisasi, subjek level 0 melakukan kesalahan pada saat memvisualisasikan sisi limas segi empat beraturan. Hal ini disebabkan gambar limas yang kurang sesuai dengan aturan geometris sehingga menyebabkan bias (ruas garis $T D$ dan ruas garis $T A$ terlihat berimpit). Subjek level 0 menyebutkan sisi limas adalah segitiga $T D B$ yang mana segitiga tersebut bukanlah salah satu dari sisi limas T.ABCD.

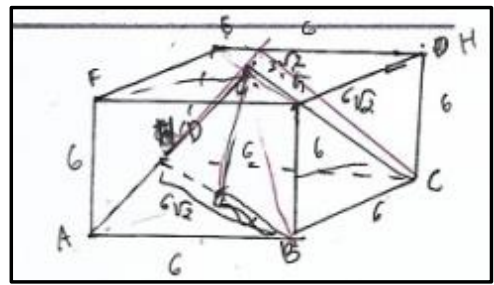

Gambar 2. konstruksi limas T.ABCD subjek level 0

Pada proses penalaran subjek level 0 tidak dapat melakukan penarikan kesimpulan dengan benar karena kesalahan dalam proses perhitungan. Hal ini disebabkan dari kesalahan visualisasi yang dilakukan di awal langkah penyelesaian soal yang menyebabkan miskonsepsi dalam menentukan sisi limas T.ABCD.

\section{Hasil Analisis Subjek Level 1 dalam Menyelesaikan Soal Geometri}

Proses konstruksi dan visualisasi yang dilakukan subjek level 1 sesuai dengan aturan geometris dan benar. Subjek level 1 mengkonstruksi segitiga $T A B$ sebagai salah satu sisi limas T.ABCD dengan garis $T O$ sebagai garis tinggi segitiga $T A B$. Untuk menentukan luas segitiga $T A B$, subjek level 1 melakukan dua langkah dengan memvisualisasikan segitiga $T F B$ dan segitiga $T O B$.

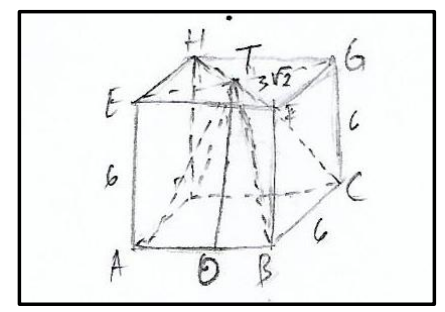

Gambar 3. konstruksi dan visualisasi limas T.ABCD subjek level 1

Pada proses penalaran, subjek level 1 melakukan kesalahan pada perhitungan pitagoras sehingga tidak dapat menarik kesimpulan dengan benar. Kesalahan 
disebabkan karena ketidaktelitian dalam operasi perhitungan luas permukaan limas T.ABCD.

3. Hasil Analisis Subjek Level 2 dalam Menyelesaikan Soal Geometri

Proses konstruksi dan visualisasi yang dilakukan subjek level 2 sesuai dengan aturan geometris dan benar. Subjek level 2 mengkonstruksi segitiga TXO untuk menentukan tinggi dari segitiga $T B C$ yang merupakan salah satu dari sisi limas segi empat T.ABCD. berbeda dengan subjek level 1, subjek level 2 hanya membutuhkan satu langkah pengkonstruksian untuk menentukan luas permukaan limas. Cara yang digunakan lebih efektif dari langkah yang dilakukan subjek level 1.

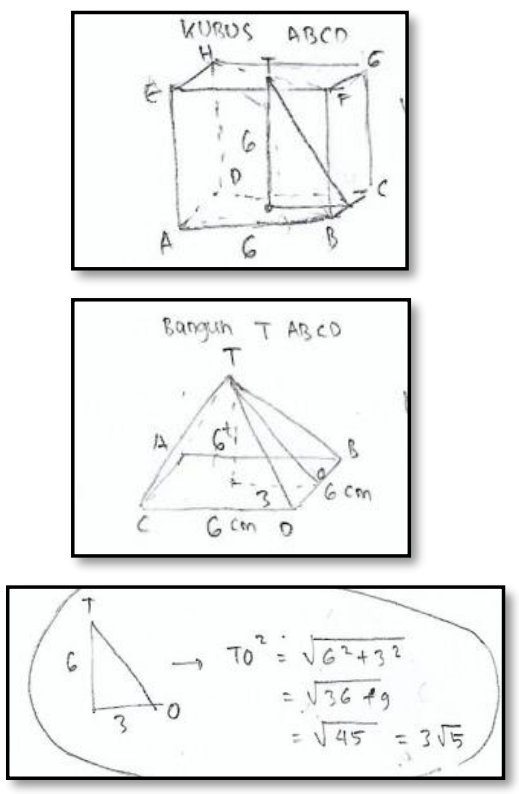

Gambar 4. visualisasi dan konstruksi subjek level 2

Subjek level 2 melakukan proses penalaran dengan baik sehingga dapat menarik kesimpulan dengan benar. Perhitungan dalam menentukan luas permukaan limas yang dilakukan subjek level 2 lebih efisien dibandingkan pada kedua subjek sebelumnya.

\section{B. PEMBAHASAN}

Berikut adalah pembahasan dari hasil analisis data penyelesaian soal geometri dan hasil analisis wawancara masing-masing subjek untuk mengetahui profil berpikir geometris siswa dalam menyelesaikan soal geometri:

\section{Profil Berpikir Geometris Subjek Level 0 dalam Menyelesaikan Soal Geometri}

Fajriah (2018) mengungkapkan pada aktivitas visualisasi terdapat dua proses yaitu proses internal dan eksternal. Proses internal dalam visualisasi yaitu membayangkan objek berdasarkan informasi yang diberikan. Dalam penelitian ini proses internal dalam visualisasi adalah mengubah bentuk geometri berdasarkan informasi yang diberikan pada soal geometri. Berdasarkan hasil analisis wawancara, subjek level 0 dapat menjelaskan bagaimana bentuk bangun limas yang dimaksud, namun dalam proses eksternal yaitu menggambarkan objek geometri, subjek level 0 salah dalam menggambarkan bangun ruang limas sehingga berakibat salah dalam memvisualisasikan salah satu sisi limas.

Subjek level 0 melakukan kesalahan dalam mempresentasikan segitiga yang menjadi sisi tegak limas. Sesuai dengan yang diungkapkan Pratama (2017) dimana keterampilan visual subjek level 0 hanya melihat secara keseluruhan tanpa menghitung perbandingan sisi-sisinya. Hal tersebut menunjukkan bahwa subjek level 0 hanya melihat secara visual sebuah objek geometri tanpa menganalisis unsur-unsur yang ada pada objek tersebut.

Dalam teori Duval, proses konstruksi berperan dalam penghubung antara proses visualisasi dan proses diskursif (Yang, 2016). Pada penelitian ini ketika subjek level 0 melakukan kesalahan dalam mengkonstruksi limas yang mengakibatkan kesalahan pada aktivitas visualisasi dan penalaran.

2. Profil Berpikir Geometris Subjek Level 1 dalam Menyelesaikan Soal Geometri

Proses visualisasi yang dilakukan subjek level 1 yaitu mempresentasikan bentuk limas berdasarkan informasi yang ada pada soal. Subjek level 1 juga memvisualisasikan salah satu sisi limas dengan benar. Hal ini dipengaruhi oleh proses konstruksi yang sesuai dengan aturan geometris yang ada. subjek level 1 menggambarkan secara rinci bentuk limas serta menjelaskan unsur-unsur yang ada dengan benar.

Pada proses penalaran, subjek level 1 melakukan kesalahan pada proses perhitungan matematis akibat ketidaktelitian yang dilakukan. Hal ini senada dengan hasil penelitian oleh Pratama (2017) bahwa subjek yang mencapai level 1 pada keterampilan aplikasi dan logikanya tidak memperhatikan satuan yang ada pada objek geometri.

Berkaitan dengan pendapat Duval yang mengatakan bahwa proses konstruksi menghubungkan antara visualisasi dan penalaran deduktif, dalam penelitian ini subjek level 1 dapat melakukan konstruksi sesuai aturan geometris sehingga pada proses visualisasi subjek level 1 dapat mempresentasikan objek geometri dengan benar. Namun kesalahan perhitungan pada aktivitas penalaran mengakibatkan kesalahan dalam penarikan kesimpulan. 


\section{Profil Berpikir Geometris Subjek Level 2 dalam Menyelesaikan Soal Geometri}

Ketiga aktivitas kognitif geometri yang dilakukan subjek level 2 sesuai dengan indikator berpikir geometris. Visualisasi yang dilakukan subjek level 2 yaitu menggambarkan bentuk geometris berdasarkan informasi yang ada pada soal. Proses visualisasi yang dilakukan subjek level 2 lebih efisien dibandingkan proses visualisasi yang dilakukukan oleh subjek level 1. Hal ini senada dengan yang diungkapkan Pratama (2017) bahwa semakin tinggi level berpikir geometris siswa maka keterampilan geometri yang dimiliki lebih baik dibandingkan siswa yang berada di level sebelumnya.

Pada penelitian Fajriah (2018) juga mengungkapkan bahwa siswa yang melakukan aktivitas konstruksi dan visualisasi dengan benar akan mempengaruhi tingkat keberhasilan penalaran yang semakin tinggi. Dalam penelitian ini, proses penalaran yang dilakukan oleh subjek level 2 didukung oleh aktivitas visualisasi dan konstruksi yang dilakukan dengan baik sehingga subjek level 2 menarik kesimpulan dengan benar.

\section{PENUTUP}

\section{A. KESIMPULAN}

Berdasarkan hasil analisis data dan pembahasan terkait profil berpikir geometris siswa berdasarkan level berpikir geometri Van Hiele yang telah dicapai, berikut adalah deskripsi profil berpikir geometris siswa dalam menyelesaikan soal geometri ditinjau dari level berpikir Van Hiele:

1. Profil berpikir geometris siswa yang mencapai level 0 level berpikir Van Hiele dalam menyelesaikan soal geometri

Siswa yang mencapai level 0 pada level berpikir geometri Van Hiele melakukan kesalahan dalam aktivitas visualisasi, konstruksi, dan penalaran. Pada aktivitas konstruksi, siswa yang mencapai level 0 menggambar objek geometri tidak sesuai aturan geometris sehingga menyebabkan kesalahan dalam memvisualisasikan objek geometri berdasarkan informasi yang diberikan. Kesalahan dalam memvisualisasikan objek geometri menyebabkan kesalahan konsep sehingga pada proses penalaran terjadi kesalahan dalam perhitungan matematis.

2. Profil berpikir geometris siswa yang mencapai level 1 level berpikir Van Hiele dalam menyelesaikan soal geometri

Siswa yang mencapai level 1 pada level berpikir geometri Van Hiele melakukan aktivitas konstruksi dan visualisasi sesuai dengan indikator berpikir geometris. Pada aktivitas penalaran, siswa melakukan kesalahan dalam proses perhitungan sehingga siswa yang mencapai level satu melakukan kesalahan dalam menarik kesimpulan.

3. Profil berpikir geometris siswa yang mencapai level 2 level berpikir Van Hiele dalam menyelesaikan soal geometri

Siswa yang mencapai level 2 pada level berpikir geometri Van Hiele melakukan aktivitas visualisasi, konstruksi, dan penalaran sesuai indikator berpikir geometris. Siswa yang mencapai level 2 juga memvisualisasikan bentuk geometri yang lebih efisien dibandingkan visualisasi yang dilakukan siswa pada level sebelumnya.

\section{B. SARAN}

1. Dari hasil penelitian yang dilakukan terdapat perbedaan proses visualisasi, konstruksi, dan penalaran yang dilakukan siswa pada setiap level yang dicapai. Oleh sebab itu guru hendaknya memperhatikan kemampuan siswa dalam pembelajaran geometri sesuai dengan level berpikir Van Hiele yang dicapai.

2. Penelitian ini terbatas pada siswa yang mencapai level 0, 1, dan 2 tingkat berpikir Van Hiele. Saran bagi peneliti lain yang akan melakukan penelitian relevan dengan penilitian ini diharapkan untuk menemukan informasi lebih lanjut mengenai proses berpikir geometris siswa yang mencapai level berpikir Van Hiele lebih tinggi.

\section{DAFTAR PUSTAKA}

Abdullah, A.H. and Zakaria, E. 2013. The Effects of Van Hiele's Phases of Learning Geometry on Students' Degree of Acquisition of Van Hiele Levels. ProcediaSocial and Behavioral Sciences vol 102: 251-266.

Aydogdu, M. Z. 2014. "A Research on Geometry Problem Solving Strategies Used by Elementary Mathematics Teacher Candidates". Journal of Educational and Instructional Studies in the World. Volume: 4 Issues: 1 Article:07.

Burton, M. David. 2011. The History of Mathematics: an Introduction $7^{\text {th }}$ Edition. New York: The McGraw-Hill Companies Inc.

Duval, R. 1995. "Geometrical Pictures: Kinds of representation and specific processing", in R. Suttherland and J. Mason (eds.), Exploiting Mental Imagery with Computers in Mathematics Education. Spinger, Berlin: pp 142-157.

Duval, R. 1998. Geometry from a Cognitive Point of View. C. Mammana and V. Villan (eds). Perspectives on the Teaching of Geometry for the 21th Century: an ICMI Study. Dordrecht: Klower. 
Duval, R. 2006. "A Cognitive Analysis of Problems of Comprehension in a Learning of Mathematics". Educational Studies in Mathematics. 61:103-131.

Fajriah, Noor. 2018. Profil Berpikir Geometris Siswa SMP dalam Memecahkan Masalah Matematika Berdasarkan Gaya Kognitif dan Gender. Disertasi tidak dipublikasikan. Surabaya: PPs Universitas Negeri Surabaya.

Fisher, Jonathan. 2015. Geometric Thinking Concept Map. (Online). (http://arbs.nzcer.org.nz/geometric-thinkingconcept-map\#introduction), diakses 24 Januari 2019)

Hardianti, D., et al. 2017. Analysis of Geometric Thinking Student's and Process-Guided Inquiry Learning Model. Journal of Physics: Conf. Ser. 895.

Jones, K. 1998. "Theoretical Framework for the Learning of Geometrical Reasoning". Proceedings of the British Society for Research into Learning Mathematics. 18(1\&2): 29-34.

Kemendikbud. 2019. Laporan Hasil Ujian Nasional. (Online). (https://puspendik.kemdikbud.go.id/hasilun/, diakses 23 Januari 2019).

Konyalioglu, A. C., et al. 2011. Visualization approach in teaching process of linear algebra. Procedia-Social and Behavioral Sciences vol 15:4040-4044.

Mufidah, Itsna. 2018. Miskonsepsi Siswa SMP dalam Memahami Konsep Bangun Datar Segiempat Ditinjau dari Gaya Belajar Vak. Skripsi tidak dipublikasikan. Surabaya: PPs Universitas Negeri Surabaya.

Ningrum, R.W. 2016. Miskonsepsi Siswa SMP pada Materi Bangun Datar Segiempat dan Alternatif Mengatasinya. Skripsi tidak dipublikasikan. Surabaya: PPs Universitas Negeri Surabaya.

Pratama, A.R. 2017. Identifikasi Keterampilan Geometri Siswa SMP Berdasarkan Tingkat Berpikir Geometri Van Hiele dalam Menyelesaikan Soal Kesebangunan. Skripsi tidak dipublikasikan. Surabaya: PPs Universitas Negeri Surabaya.

Puspitasari, R.A. 2018. Misconception on 3 Dimensional Figure with Flat Sides by Using Certainty of Response Index (CRI) Method. Skripsi tidak dipublikasikan. Surabaya: PPs Universitas Negeri Surabaya.

Sofyana, Aisia U. 2013. Profil Keterampilan Geometri Siswa SMP dalam Memecahkan Masalah Geometri Berdasarkan Level Perkembangan Berpikir Van Hiele. Skripsi tidak dipublikasikan. Surabaya: PPs Universitas Negeri Surabaya.

Sunardi. 2005. Pengembangan Model Pembelajaran Geometri Berbasis Teori Van Hiele. Disertasi tidak dipublikasikan. Surabaya: PPs Universitas Negeri Surabaya.

Walle, John A.V.D. 2001. Geometric Thinking and Geometric Concepts $4^{\text {th }}$ Edition. Boston: Allyn and Bacon.
Walle, John A. V.D. 2010. Elementary and Middle School Mathematics: Teaching Developmentally $7^{\text {th }}$ Edition. US: Pearson.

Yang, K.-L. \& Li, J.-L. 2016. A framework for assessing reading comprehension of geometric construction texts. International Journal of Science and Mathematics Education. 109-124. 
PROFIL BERPIKIR GEOMETRIS 